\title{
Research
}

\section{Identifying Areas for Field Conservation of Forages in Latin American Disturbed Environments}

\author{
$\underline{\text { Michael Peters }}^{1}, \underline{\text { Glenn Hyman }}^{1}$, and $\underline{\text { Peter Jones }}^{1}$
}

\begin{abstract}
This paper uses the spatial analysis tools DIVA and FloraMap to identify potential areas for the in situ conservation of a set of 10 forage species. We introduce the idea of roadside verges as conservation areas and discuss the risks and opportunities of two potential scenarios for conservation. These are the introduction of mass reservoirs outside of the original areas of collection and conservation inside the area of origin. Four potential areas for in situ conservation in Latin America are identified. Although more detailed studies using remote sensing, soil information, and field reconnaissance will be necessary for a final assessment of the suggested areas as field conservation sites, we discuss the possibilities of establishing low-maintenance communities and the potential dangers of introducing harmful weed species. We do not have final answers with regard to the permanent maintenance of genetic diversity in these areas but suggest that further studies of genetic drift in the populations would not only be scientifically useful but might also lead to identifying useful genotypes for local use.
\end{abstract}

Key Words: biodiversity, distribution, DIVA, FloraMap, forages, germplasm, Latin America, legumes, roadside, spatial analysis, verges.

\section{INTRODUCTION}

Population pressure and the destruction of ecosystems lead to genetic erosion and loss of biodiversity (Hodgkin 1997). The effects of global warming and water shortages may further compound the problems of loss of specific plant species and accessions (International Plant Genetic Resources Institute 1999), which could have potentially severe consequences for long-term food security and the environment (McNeely and Scherr 2002). This is particularly true for wild species such as most tropical forages. For example, SchultzeKraft et al. (1993) failed to find germplasm of Arachis pintoi Krapov. \& W. Gregory and Centrosema acutifolium Benth. at well-documented original collection sites in central Brazil, suggesting that these plant resources had been lost because of changes in the land cover.

Recent World Summits on Sustainable Development (Rio de Janeiro in 1992 and Johannesburg in 2002) have emphasized the threat to future food security from the genetic erosion of useful crop and forage plants. Ex situ conservation in gene banks supports genetic integrity, the security of collections, and easy access, but it requires cautious management and is therefore costly. Moreover, many collections in tropical countries, often without backup, are threatened by theft and ransacking because of civil unrest and an unreliable electricity supply (International Plant Genetic Resources Institute 1999).

In situ conservation can complement ex situ conservation, thus limiting these threats, and allows for the continuing evolution and adaptation of plant species (Williams 1991, International Plant Genetic Resources Institute 1999). However, to be successful, in situ conservation projects need to pay attention to the socioeconomic components of biodiversity (Brush 2000). In fact, because large areas must be set aside for all time, in situ conservation can be even more expensive than germplasm collections. Strategies and management for in situ conservation lack clarity and warrant 
further research (International Plant Genetic Resources Institute 1999). This is especially true for forages, because international agricultural research centers have so far concentrated on ex situ conservation in gene banks (Maass et al. 1997).

Traditionally, in situ conservation is seen as the maintenance of genetic resources in their natural habitats (Maxted et al. 1997). Brush (1995, 2000) describes on-farm conservation mainly for land races as a subset of in situ conservation. In this paper, we concentrate on the field conservation of forages that could also be considered a subset of in situ conservation. Because many forage plants have evolved in environments affected by human or animal activity, it is highly likely that they can be conserved in disturbed environments with less restriction of use than required in natural reserves. The number of natural reserves is limited, and the approach we suggest could complement conservation in natural habitats.

A particularly attractive option is the conservation of forages along roadsides, which would have the additional benefit of providing vegetation cover to stabilize the shoulder against erosion or mass movement. Latin America has only 3\% of the world's roads, of which fewer than $20 \%$ are paved; all have general problems with maintenance. However, there are more than $10,000 \mathrm{~km}$ of freeways (Keeling 2002), and there is a growing trend toward the development of public toll roads managed by the private sector (Vera Aguirre 1997). The verges of major roads in Latin America are mainly herbaceous and publicly owned. Often they are cut or grazed to maintain low, disturbed vegetation as part of normal road maintenance. Apart from establishment and monitoring, the costs for maintenance of roadside forage conservation areas are not envisaged to be much greater than those that road maintenance authorities currently incur. In some areas, the roadsides are cultivated. These areas would not be selected when identified in further analysis.

We address two potential scenarios for in situ conservation. The first concerns conservation in areas of origin. In this scenario, it is important to identify the areas that provide a high concentration of biodiversity, because these are priority areas for protection that would make it possible to maximize the use of conservation resources. The second scenario involves mass reservoirs that concentrate species in environments suitable for a large range of forages, although not necessarily within their areas of origin. Conservation practitioners consider this type of approach somewhat controversial. Although maximizing resource use is an important goal, at the same time conservation specialists need to focus on the loss of genetic diversity in introduced collections and on the replacement of native vegetation. On the other hand, such an approach may provide a way to select forage materials suitable to particular environments and allow for the continuing generation of genetic diversity in the face of new threats such as climate change and drought (D. G. Debouck, personal communication).

Many, if not most, agriculturally useful plants are colonizers that require disturbed environments. The forage legumes we have chosen for this study are typical and therefore good candidates for roadside conservation. To make roadside conservation efficient, it must be feasible to jointly manage a reasonable range of species. This study is therefore a pilot to see if we can find areas where up to 10 of these potentially useful forage legume species might be handled in this manner. If this is possible, it might be so for many more forages, pasture species, and wild crop relatives.

\section{METHODS}

Forage species were selected based on the size of the collections held in the germplasm banks at the Consultative Group on International Agricultural Research (CGIAR), the importance of the individual species, and our knowledge of them. Stylosanthes sp. is probably the most researched and widely distributed genus of tropical forage legumes, with $S$. guianensis (Aublet) Sw. and S. scabra Vogel best adapted to acid soils, although the pH-neutral S. hamata (L.) Taubert is probably the best known. These are complemented with $S$. viscosa Sw. and $S$. capitata Vogel. Centrosema pubescens Benth., $C$. macrocarpum Benth., and $C$. brasilianum (L.) Benth. have been researched in depth (SchultzeKraft et al. 1997). C. pubescens is broadly distributed in the tropics as feed, cover crop, and green manure. More recent interest in forage legumes has been in Arachis pintoi, which has initially been used as pasture in grass legume associations and as cover in plantations (Rivas and Holmann 1997, Wünscher et al. 2004). Aeschynomene histrix Poiret has been adopted in West Africa as forage and for improved fallow (R. Schultze-Kraft, personal communication). 


\section{Calculating species richness}

To analyze Scenario 1, which identifies priority areas for conservation of forages in their areas of origin, we calculated species richness. Our aim was to find places with maximum species diversity for the 10 forage species studied. Using DIVA-GIS software (Hijmans et al. 2001), we placed an arbitrary 1 degree sampling frame over the Latin American study area. Species richness is the number of different species within each 1-degree grid cell. This species richness index is highly dependent on the availability of a collected accession for each site. A positive value indicates diversity; a low or zero value may indicate a lack of knowledge rather than low diversity.

\section{The FloraMap method}

The potential for field conservation of the core collection was estimated using FloraMap®, a software package for predicting the distribution of plants and other organisms in the wild. It uses the climate data from a set of known collection points at which the species has been found to build a model of the probability of finding the organism in a given climate and can be used to produce a map. The algorithm was originally published in Jones et al. (1997), and was used in its original FORTRAN for a number of studies (e.g., Sawkins et al. 1999). It was subsequently released as a complete version for Windows ${ }^{\circledR}$ (Jones and Gladkov 1999). FloraMap ${ }^{\circledR}$ has been used successfully on many species, including the wild bean Phaseolus vulgaris L. (P. G. Jones and S. Beebe, unpublished manuscript; for a summary of this poster presentation, click here), Passiflora sp. (S. D. Segura et al., unpublished manuscript), and Arachis sp., the wild relatives of the peanut (Jarvis et al. 2002).

Using FloraMap, we addressed the second conservation scenario, which conserves forage species in mass reservoirs outside the area of origin. FloraMap uses climatic data from a 10 min grid corresponding to $18 \times 18 \mathrm{~km}$ at the equator interpolated with observations from approximately 11,000 meteorological stations in Latin America. The interpolation algorithm is based on the inverse square of the distance between the five stations closest to the interpolated pixel. The climatic variables included were the monthly averages for temperature, rainfall, and diurnal temperature range. Mean temperature was standardized with elevation using the NOAA TGP-006 (National Oceanographic and Atmospheric Administration 1984) digital elevation model and a lapse rate model (Jones 1991). In the climate grids used for this study, rainfall and diurnal temperature range remained independent of elevation. A 12-point Fourier transform was applied to each variable to adjust for geographic differences in the timing of major seasons (Jones et al. 1997, 2002).

For each accession, 12 monthly means for temperature, 12 monthly rainfall totals, and 12 monthly mean diurnal temperature ranges were extracted for the pixel in which the accession is located. The rainfall totals were transformed to approximate normality with a square-root transform. A principal components analysis (PCA) was applied to identify a smaller number of variables that accounted for the bulk of the variance in climates among the accession locations. The PCA was performed on the variance-covariance matrix to maintain the weightings between the variates. A multivariate-Normal distribution was fitted to the principal component scores, and the multidimensional probability of belonging to the distribution could then be calculated for all pixels. The result was a probability surface for all of Latin America.

This method used only climate data at this stage and was a quick analysis for the whole continent based on interpolated climate surfaces that were readily available. Once relevant areas had been identified, further analysis would take into account soils and other data from remote sensing images. To include all of these data at the same stage would have been difficult and unnecessarily time-consuming.

\section{Sample size and sensitivity}

Although FloraMap has already been used on many species, few studies take into account the sensitivity of the analysis to sample size. Jones and Gladkov (1999) suggest that samples based on fewer than 20 accessions may give spurious results, but this is merely a lower limit. We therefore looked at this aspect to assure ourselves that the samples we were using were adequate for the job. First, we divided each sample randomly into two halves and compared the distribution maps produced for each species. Figure 1 shows a typical example for Centrosema pubescens, now C. molle Mart. ex Benth. (Fantz 1996, Schultze-Kraft 2003). The maps show almost identical distribution patterns 
with only minimal differences in the pattern of climate similarity. Thus, randomly selecting only half of the points in the sample did not appear to change the resulting pattern. We decided to put the data to an even stronger test. We selected $10 \%$ of the sample points at random and used these to compare the distribution map with the full sample. Figure 2 shows a typical example for S. scabra. Although there are minor differences in the $10 \%$ distribution, the overall pattern is remarkably similar to that of the full sample.

To compare a pair of images, we chose only those pixels that had a probability of at least 0.01 in both images. This eliminated large areas in which the probability model in both cases would yield a zero because the climate was extreme for this species, biasing any statistical test. This yielded 41,478 pixels for Fig. 1 and 35,947 pixels for Fig. 2 out of 64,740 for the complete map. We classed the probabilities into four even groups and constructed a 4 x 4 chi-squared table to test for similar distribution. The chi-squared values with nine degrees of freedom were 63,697 for Fig. 1 and 42,862 for Fig. 2, both giving probability values of less than 0.0001 under the null hypothesis that the distributions were randomly associated.

We therefore concluded that the sample sizes we had for this study were adequate to represent the full distributions of the species studied.

\section{Combining probability surfaces}

Determining the best in situ conservation sites for the greatest number of the 10 species examined in this study required the combination of the 10 probability surfaces. We tried a number of different ways to combine the probabilities; most were unsatisfactory, but one appeared to give us what we needed:

$$
p=\frac{1}{n} \sum_{i=1}^{n}\left(p_{i} \geq a\right)
$$

Equation 1 forms an index from the number of species in which the probability, $p_{\mathrm{i}}$, exceeds a threshold, $a$. We chose a threshold probability of 0.5 and used this equation to map species richness. Because this index is free from actual accession observation, a low or zero value indicates low probable diversity and not just a lack of knowledge, as in the case of DIVA.

\section{Defining potential road verges}

To determine the potential for establishing in situ conservation sites along roadsides, we used digital road maps of Latin America and the Caribbean at 1:1,000,000 scale, based on the Digital Chart of the World or DCW (Environmental Systems Research Institute 1993). We improved this map where possible by adding finer-scale data from national road maps (Ministerio del Ambiente y de los Recursos Naturales Renovables 1989, Editora Abril 1992, Instituto Geográfico Nacional Tegucigalpa 1997, Instituto Nicaragüense de Estudios Territoriales 1997) to supplement the DCW and allow us to verify road conditions. These maps were then overlaid on the species richness maps to determine the probable sites with accessible lengths of roadside environment suitable for the joint conservation of the maximum number of species.

Climate grids are available on the FloraMap Website for all of the tropics, mainland USA, and Europe for those who wish to do similar analyses for these areas.

\section{RESULTS}

\section{Evaluating diversity in the areas of origin: Scenario 1}

Most of the 10 forage species studies were collected in Central America, Colombia, Venezuela, and southern and eastern Brazil (Fig. 3). The map shows four areas in which six or more forage species were found within the same 1-degree grid cell. These include an area in Central Panama near the town of Anton, an area in eastern Venezuela between Cumana on the coast and El Tigre to the south, and two areas in Brazil from Salvador westwards into Bahia State and in central Mato Grosso. The Venezuelan site showed the highest concentration of forage species richness. 
Fig. 1. Probability distribution of Centrocema pubescens with the sample divided into two random equal halves.

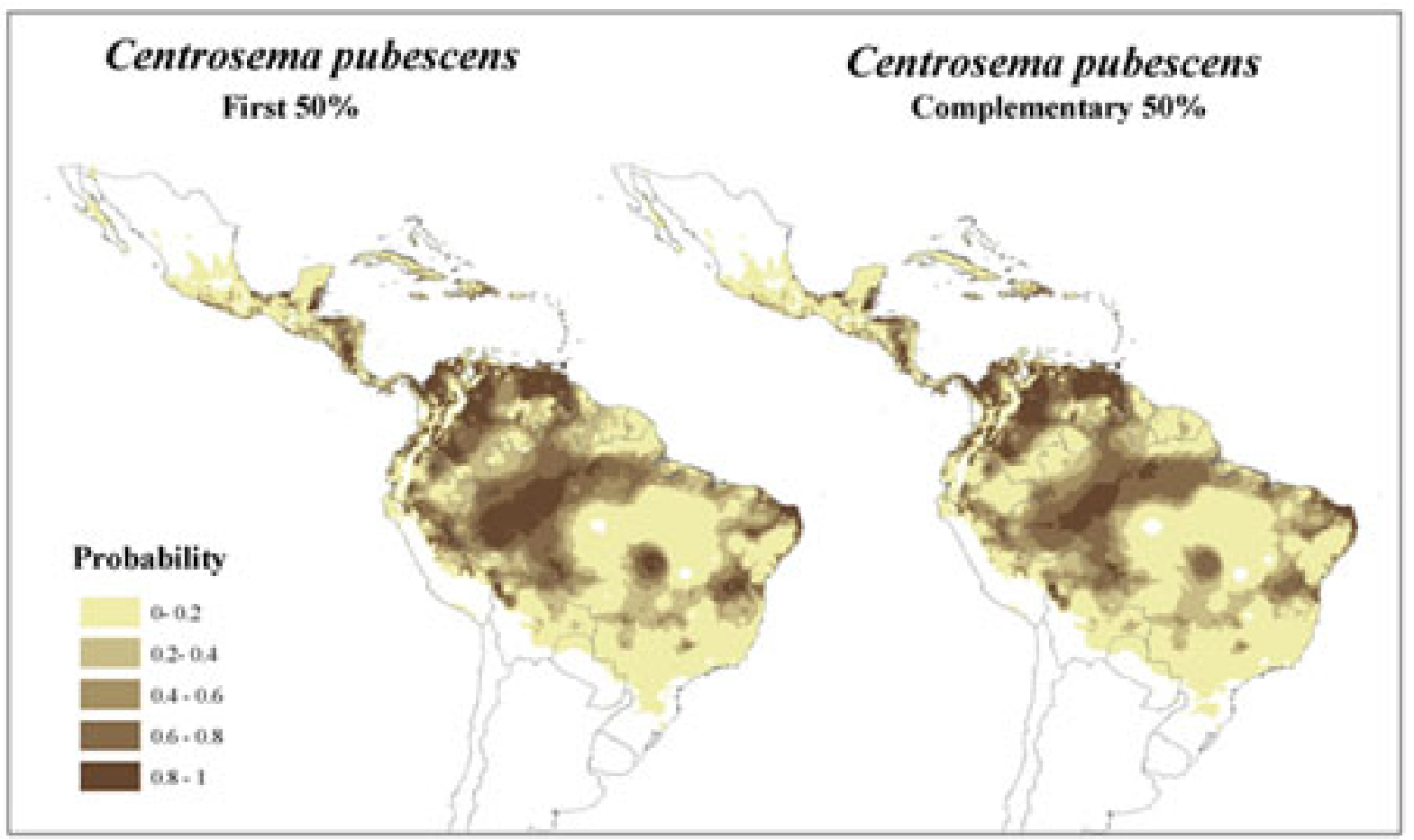

\section{Evaluating diversity for mass reservoirs outside of areas of origin: Scenario 2}

We produced individual distribution maps for each species, including the accession points used to calibrate each model (Fig. 4). Most species have been collected in Brazil and in either the Andean countries or Central America. Among the five Stylosanthes species covered here, the exception is S. hamata, which is found on and adapted to the less acid soils of the Caribbean Basin. Nevertheless, it is present in coastal Brazil, as shown by the three accessions found in Bahia. The potential distribution of $S$. hamata is therefore far wider than its collection footprint, found wherever soil conditions would permit. All three of the Centrosema species have been collected in many areas and have broad potential distributions, even though $C$. brasilianum has not been found widely in Central America. Arachis pintoi in the wild is endemic to Brazil, Paraguay, and Bolivia. Although all the accessions used in this model came from Brazil, the model correctly identifies the other endemic areas. A. pintoi is widely adapted as a pasture species and has now been introduced into many of the areas indicated in Central America and Colombia.

Potential areas for in situ conservation outside of areas of origin were calculated from these 10 distribution maps. Figure 5 shows the concentration of the species whose probability of finding an environment similar to their areas of origin is greater than $50 \%$. We overlaid this map on the road distribution and selected those areas in which significant numbers of pixels with a high species richness index also showed major road access. This eliminated two significant areas: the first in western Brazil, where access is limited, and the second in Venezuela, south of the Orinoco, which is likewise highly remote. We selected five areas for more detailed study. 
Fig. 2. Probability distribution of Stylosanthes scabra with the sample divided into random selections of $10 \%$ and $100 \%$ of the sample.

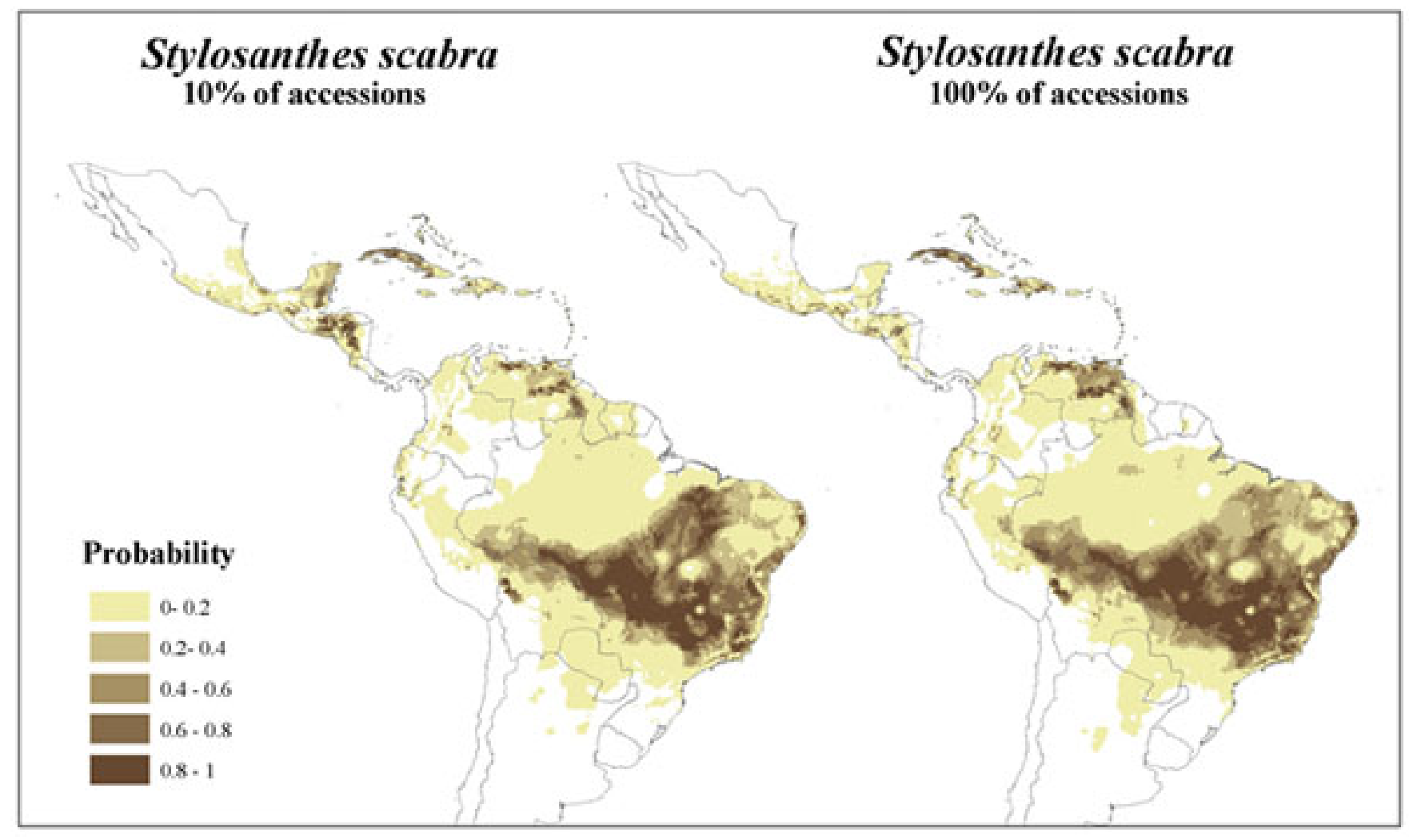

Figure 6 shows the two areas selected in Brazil. Both of these areas are well supplied with roads, and the potential for conservation sites could be good. The area southeast of Danlí in Honduras (Fig. 7) shows potential areas in which all 10 species might be sympatric. In Nicaragua, a broader area with a high species richness index coincides with a good network of main, but unpaved, roads. The area selected in Bolivia is quite remote, and although climatically suitable, it may not be a good proposition. Venezuela is well supplied with potential sites (Fig. 8).

\section{DISCUSSION}

\section{Can we form stable associations of legume species?}

Results from work with legume mixtures show that, through compensation and complementation of individual legume species, mixtures are seasonally and temporally more stable than single stands. The complementarity of species signifies that, although some less competitive species may reduce in the sward over time, a stable mixture of several species in a sward can be formed (Wolf and Southwood 1980, Aiken et al. 1991, Peters et al. 1999, 2000, Tarawali et al. 1999). Successful legumes have included Stylosanthes, tree legumes, and niche legumes such as forage Arachis species. Their characteristics varied greatly but, with some 
Fig. 3. Species richness of 10 forage species in Latin America.

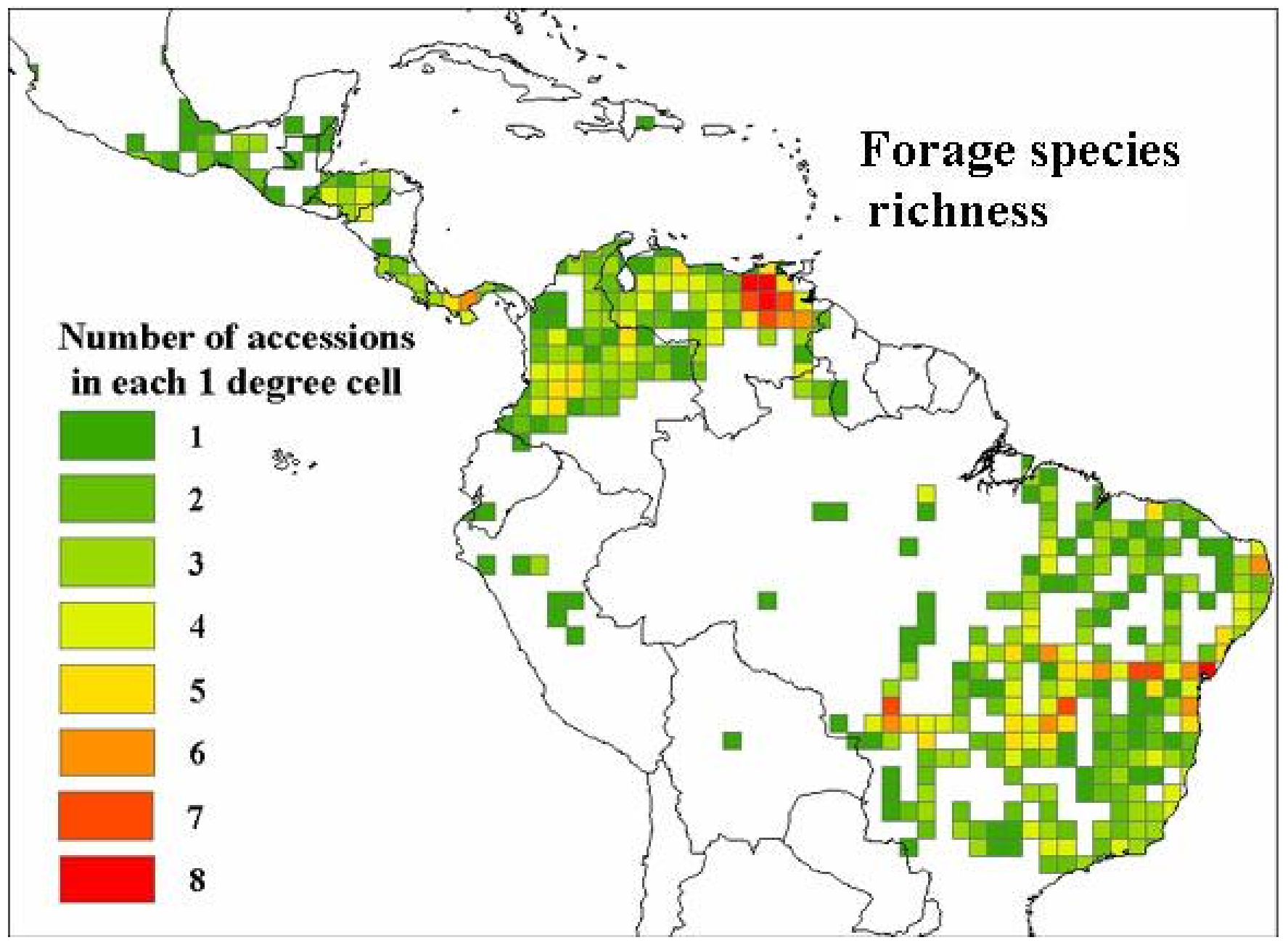

exceptions, they demonstrated persistence, vigor, and longevity under grazing or cut-and-carry systems; except for Leucaena, they were easy to establish; and they either had high seed yield or were easy to propagate.

Fig. 4. Accession points and predicted distribution of Aechynomene histrix, Stylosanthes capitata, Stylosanthes hamata, Stylosanthes viscosa, Stylosanthes scabra, Stylosanthes guianensis, Arachis pintoi, Centrosema brasilianum, Centrosema macrocarpum, and Centrosema pubescens.
This figure is available only online. Please visit http://www.ecologyandsociety.org/vollo/iss 1/art1/

\section{Genetic drift within the populations}

Genetic drift is expected in the populations once they have been established (Gale and Lawrence 1984), but, by selecting the areas that are the most climatically similar to the areas of origin, we hope that this will be minimized. Legume persistence in tropical pastures can be problematic under heavy grazing pressure but is much easier to control under 
Fig. 5. Potential areas for in situ conservation outside areas of origin. The concentration of species whose probability of finding an environment similar to their areas of origin is greater than $50 \%$.

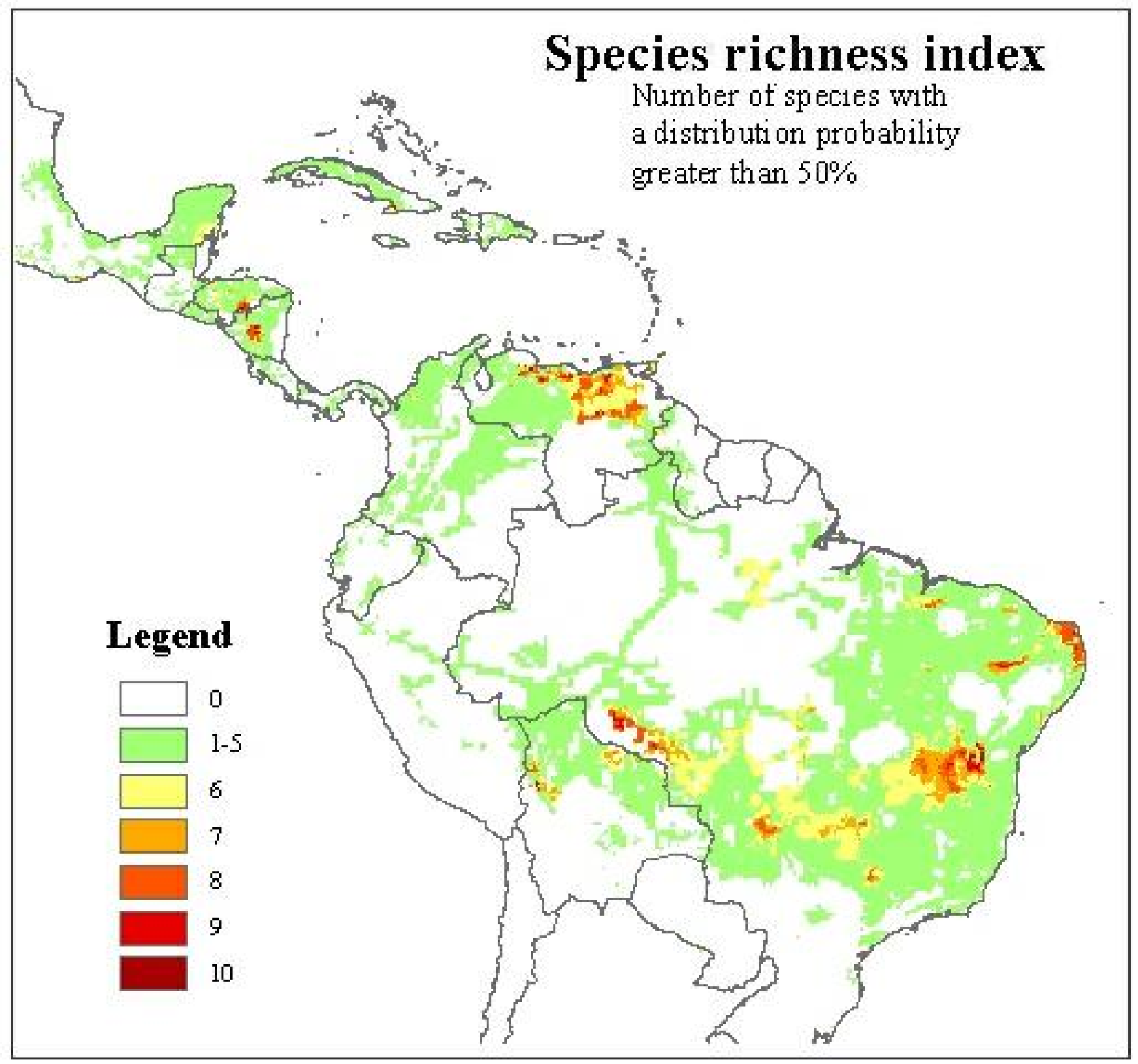

light grazing (Lascano 2001). There are a few exceptions to this rule, because legumes such as Arachis pintoi and Desmodium hetercarpon subsp. ovalifolium require heavy grazing for persistence (Lascano 1994, Schmidt et al. 2001). Road verges often have a variety of these characteristics.

We propose that test ecotypes be taken from a core collection of each species (Brown 1989, 1995, van Hintum 1999) to make sure that the full range of 
Fig. 6. Details of selected Brazilian areas.
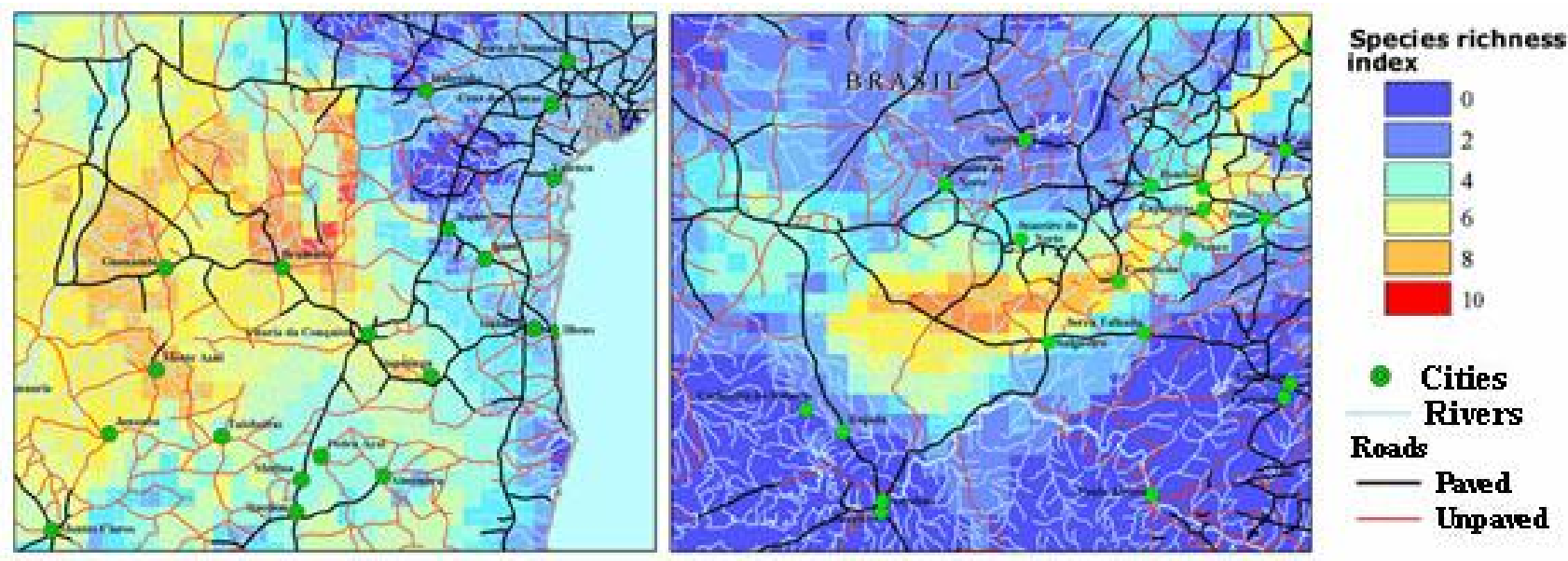

Fig. 7. Details of areas selected in Central America and Bolivia.
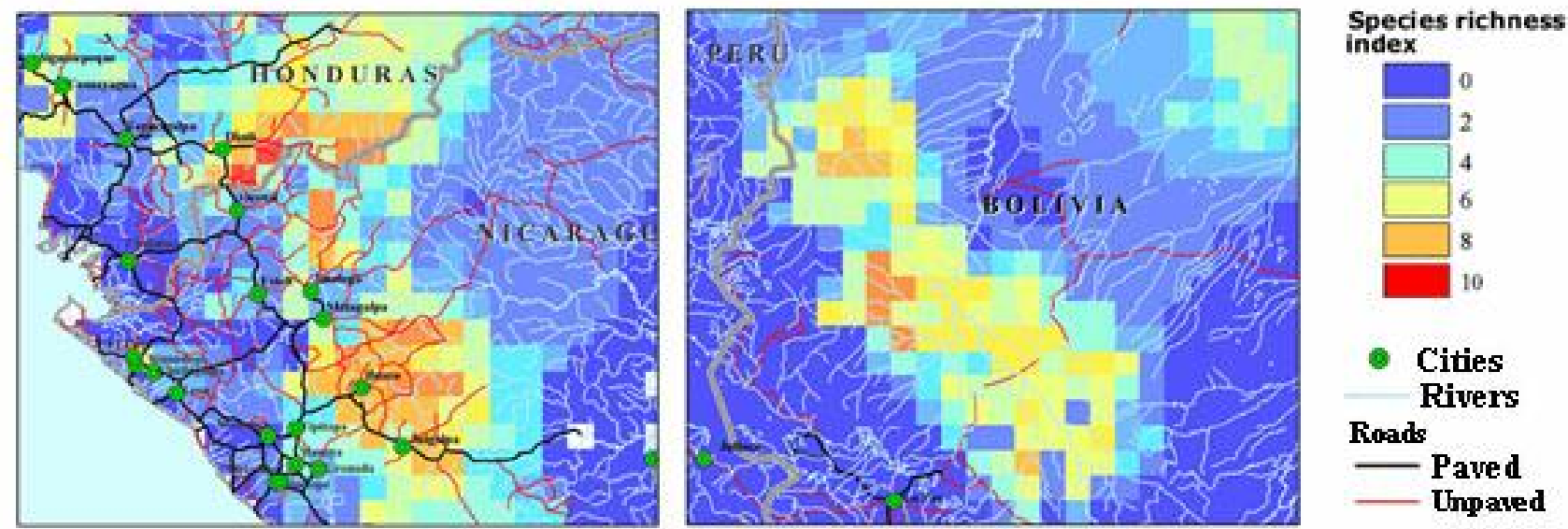

available genetic variation is included. A general problem when emphasizing areas of species richness is that it is easy to miss outliers of plant species with particular characteristics. Conversely, an area suitable for all 10 species may mean that some or all will be only marginally adapted, resulting in rapid selection and genetic drift. We have attempted to limit this possibility by requiring a high threshold probability of 0.5 for the inclusion of a species in the diversity index, but we accept that the roadside sites will not guarantee full conservation of a collection. Having a range of sites may be necessary to conserve as much diversity as possible. 
Fig. 8. Details of selected area in Venezuela.
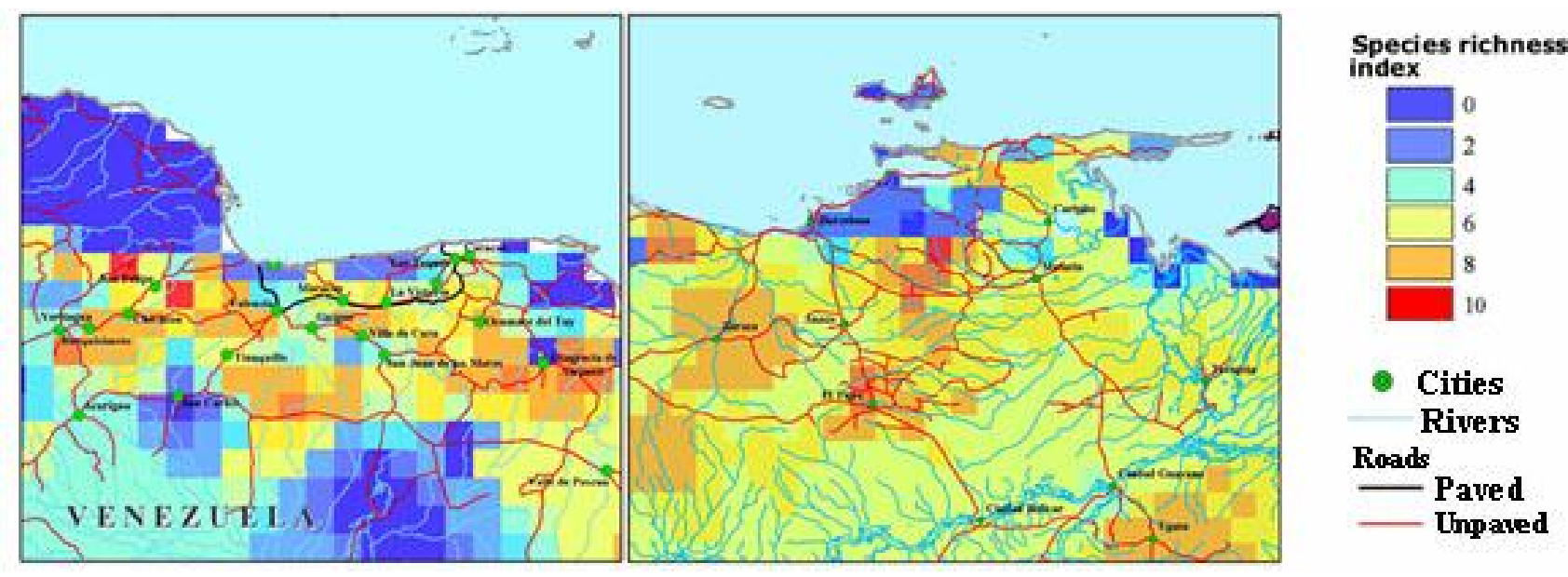

\section{Weed problems}

When proposing the establishment of mass conservation areas outside the area of origin of the forages, there is naturally the risk that some species may become aggressive weeds, particularly pasture species chosen for their ability to maintain themselves under grazing pressure. Indeed, farmers in Latin America have established the African grasses, Brachiaria and Andropogon, so widely that in some areas they are regarded as weeds when cultivation is chosen. Care should be taken with some of the forage species in this study, particularly with Arachis pintoi, which may transmit a virus of the common bean. However, A. pintoi is already widespread in many areas, both as a pasture species and as a ground cover for coffee (Coffea arabica L.).

\section{The difference between FloraMap and DIVA}

The coincidence between the species richness maps produced by the DIVA and FloraMap methods in those areas in which accessions actually occurred gives us confidence in the FloraMap analysis. The advantage of the latter method is that it can predict potential areas without the necessity of actually having observed the plants there. However, the DIVA analysis guarantees that all species actually have been present in the area selected, so it may be the most appropriate for strict conservation in areas of known origin.

\section{Conservation in areas of origin}

Our results suggest that four areas could hold suitable sites for in situ conservation in the areas of origin for eight forage species (Fig. 3). Because there is only a limited risk involved in establishing conservation plots in these areas of origin, our maps identify priority areas that can guide conservation specialists and policy makers.

Detailed mapping and local knowledge of these potential sites are needed to plan for pilot projects. The potential sites that we identified can be studied in greater detail using remote sensing data. Highresolution imagery or aerial photographs could possibly provide useful information, even about the verges. Soil information is needed to assess the diversity of soil environments for conservation sites. If a detailed soil map of the area is available, this assessment could be carried out in the office. Eventually, researchers and local experts will need to carry out field reconnaissance to verify whether the identified sites could be set up as conservation areas. 


\section{Mass reservoirs, not necessarily in areas of origin}

An advantage of having an in situ conservation area with public access in a location in which forage legumes already have a niche in the farming system is that the local population will serve as an ongoing adaptation trial. Eventually, farmers will be able to select, directly from the conservation area, promising ecotypes well suited to their locale. Thus, mass reservoirs can be seen to fulfill two roles, that of conservation and that of selection of adapted material. These could be viewed as conflicting purposes and may require careful balancing.

Detailed studies under controlled conditions are necessary to assess the implications of such reservoirs. The areas around El Tigre, Venezuela, and in Bahia State in Brazil may provide ideal study grounds because they combine locations suitable for both conservation in the areas of origin (Fig. 3) and mass reservoirs (Fig. 5), hence reducing the risks of genetic drift and the introduction of harmful weeds.

\section{Setting up the areas}

Local partners such as national agricultural research systems, universities, farmer groups, and/or schools could participate in the conservation program to supervise the minimal monitoring of any established conservation area. It is too early to suggest what sort of planting pattern would be appropriate for which areas. This should be the object of further research once areas have been identified. Protocols would need to be established for monitoring the conservation sites and collecting data on forage health, yield, and other characteristics. The establishment of the sites would need to be coordinated with transportation authorities to ensure that permission is obtained and the site is maintained and protected. In cases in which road maintenance is contracted to a private company, arrangements must be made for their participation. Because transportation development is often viewed as a threat to biodiversity, governments may see these conservation programs as a way to limit environmental damage and enhance their image.

In setting up these sites, any conservation program must take into account both national ownership of germplasm and plant quarantine issues. Through an international in situ conservation program with multiple sites, we expect that individual countries would continue to recognize the value of the international exchange of germplasm.

\section{Maintenance}

We hope that, under the normal maintenance conditions of the roadsides, low-density populations of the legumes could be established such that minimal extra intervention will be necessary to maintain them. It may well be the case that different maintenance conditions will be needed for legumes with varying plant habit. Low-growing Arachis will need shorter vegetation than some of the more upright species and may prefer roadsides that are grazed. In this case, it will be best to suit the range of species to be conserved to the prevailing maintenance regime rather than cause the highway management to incur extra cost. In any case, the persistence and genetic diversity of populations of each species will be subject to experiment.

\section{CONCLUSIONS}

This study used temperature, precipitation, elevation, transportation infrastructure, and species passport information to select possible locations for the in situ conservation of plant genetic resources on roadsides. We have shown that, using geographic information systems (GIS) technology, sites can be found in which multiple species with distinctive distributions might be brought together to coexist. There may be biological problems to overcome, and we have outlined some of them with possible solutions and caveats. However, it would appear that there could be a good precedent for putting together easily maintained mixtures of legume species. The actual operation of this type of conservation will require local support; we feel that this is eminently feasible and should be tried. If it can be made to work with forage legumes, it might be an option with other colonizing species and provide a low-cost solution to the conservation of valuable wild crop relatives.

Responses to this article can be read online at: http://www.ecologyandsociety.org/vollo/iss 1/art1/responses/ 


\section{Acknowledgments:}

We thank Belisario Hincapié, German Lema, G. Ramírez, and Victor Soto for data processing and statistical analysis, Elizabeth Barona for cartographic work, and Dr. Daniel Debouck for critical assessment and comments on the manuscript.

\section{LITERATURE CITED}

Aiken, G. E., W. D. Pitman, C. G. Chambliss, and K. M. Portier. 1991. Plant responses to stocking rate in a sub-tropical grass-legume pasture. Agronomy Journal 83:124-129.

Brown, A. H. D. 1989. Core collections: a practical approach to genetic resources management. Genome 31: 818-824.

Brown, A. H. D. 1995. The core collection at the crossroads. Pages 3-19 in T. Hodgkin, A. H. D. Brown, T. J. L. van Hintum, and E. A. V. Morales, editors. Core collections of plant genetic resources. Wiley, Chichester, UK.

Brush, S. B. 1995. in situ conservation of landraces in centers of crop diversity. Crop Science 35:346-354.

Brush, S. B. 2000. The issues of in situ conservation of crop genetic resources. Pages 3-26 in S. B. Brush, editor. Genes in the field: on-farm conservation of crop diversity. International Plant Genetic Resources Institute, International Development Research Centre, Ottawa, Canada, and Lewis Publishers, Boca Raton, Florida, USA.

Editora Abril. 1992. Guia rodoviário. Editora Abril, São Paulo, Brazil.

Environmental Systems Research Institute. 1993. Digital chart of the world. ESRI, Redlands, California, USA.

Fantz, P. R. 1996. Taxonomic notes on the Centrosema pubescens Bentham complex in Central America (Leguminosae: Phaseoleae: Clitoriinae). SIDA Contributions to Botany 17
(2):321-332.

Gale, J., and M. Lawrence. 1984. The decay of variability. Pages 77-85 in J. H. W. Holden, and J. T. Williams, editors. Crop genetic resources: conservation and evaluation. George Allen \& Unwin, London, UK.

Hijmans, R. J., L. Guarino, M. Cruz, and E. Rojas. 2001. Computer tools for spatial analysis of plant genetic resources data. 1. DIVA-GIS. Plant Genetic Resources Newsletter 127:15-19.

Hodgkin, T. 1997. Some current issues in the conservation and use of plant genetic resources. Pages 3-10 in W. G. Ayad, T. Hodgkin, A. Jaradat, and V. R. Rao, editors. Molecular genetic techniques for plant genetic resources. Report of an International Plant Genetic Resources Institute Workshop, 9-11 October 1995, Rome, Italy. Available online at:

http://www.ipgri.cgiar.org/publications/

HTMLPublications/675/ch2.htm.

Instituto Geográfico Nacional Tegucigalpa. 1997. Mapa oficial: República de Honduras. IGNT, Tegucigalpa, Honduras.

Instituto Nicaragüense de Estudios Territoriales. 1997. República de Nicaragua: mapa de divisiones políticas administrativas. INET, Managua, Nicaragua.

International Plant Genetic Resources Institute. 1999. Diversity for development; the new strategy of the International Plant Genetic Resources Insititute. IPGRI, Rome, Italy.

Jarvis, A., M. E. Ferguson, D. E. Williams, L. Guarino, P. G. Jones, H. T. Stalker, J. F. M. Valls, R. N. Pittman, C. E. Simpson, and P. Bramel. 2002. Biogeography of wild Arachis: assessing conservation status and setting future priorities. Crop Science 43:1100-1108.

Jones, P. G. 1991. The CIAT climate database version 3.41, machine-readable dataset. Centro Internacional de Agriculture Tropical (CIAT), Calí, Colombia.

Jones, P. G., and A. Gladkov. 1999. FloraMap Version 1.0: a computer tool for predicting the distribution of plants and other organisms in the wild. CD-ROM series. Centro Internacional de Agricultura Tropical (CIAT), Calí, Colombia. 
Jones, P. G., N. Galwey, S. E. Beebe, and J. Tohme. 1997. The use of geographical information systems in biodiversity exploration and conservation. Biodiversity and Conservation 6:947-958.

Jones, P. G., L. Guarino, and A. Jarvis. 2002. Computer tools for spatial analysis of plant genetic resources data: 2 FloraMap. Plant Genetic Resources Newsletter 130:6-10.

Keeling, D. J. 2002. Transportation challenges for Latin America in the 21st century. Pages 77-103 in G. Knapp, editor. Latin America in the 21st century: challenges and solutions. University of Texas Press, Austin, Texas, USA.

Lascano, C. E. 1994. Nutritive value and animal production of forage Arachis. Pages 109-121 in P. C. Kerridge and B. Hardy, editors. Biology and agronomy of forage Arachis. Publication no. 240. Centro Internacional de Agricultura Tropical (CIAT), Calí, Colombia.

Lascano, C. E. 2001. Animal production in grasslegume pastures. Pages 219-232 in A. SotomayorRios and W. D. Pitamn, editors. Tropical forage plants: development and use. CRC Press, Boca Raton, Florida, USA.

Maass, B. L., J. Hanson, L. D. Robertson, P. C. Kerridge, and A. M. Abd El Moneim. 1997. Forages. Pages 321-348 in D. Fuccillo, L. Sears, and P. Stapleton, editors. Biodiversity in trust. Cambridge University Press, Cambridge, UK.

Maxted, N., B. Ford-Lloyd, and J. G. Hawkes. 1997. Plant genetic conservation: the in situ approach. Chapman and Hall, London, UK.

McNeely, J. A., and S. Scherr. 2002. Ecoagriculture: strategies to feed the world and save biodiversity. Island Press, Washington, D.C., USA.

Ministerio del Ambiente y de los Recursos Naturales Renovables. 1989. Mapa físico de la República de Venezuela. MARNR, Caracas, Venezuela.

National Oceanographic and Atmospheric Administration. 1984. TGPO006 D computercompatible tape. NOAA, Boulder, Colorado, USA.
Peters, M., S. A. Tarawali, and R. Schultze-Kraft. 2000. Relative palatability and seasonal agronomic performance of selected pasture legumes for species mixtures in subhumid West Africa. Experimental Agriculture 36:1-16.

Peters M., S. A. Tarawali, R. Schultze-Kraft, J. W. Smith, and A. Musa. 1999. Performance of legume mixtures under small-plot periodic grazing. Journal of Agronomy and Crop Science 182:25-35.

Rivas, L., and F. Holmann. 1997. Adopción temprana de Arachis pintoi en el trópico húmedo: el caso de los sistemas ganaderos de doble propísito en el Caquetá, Colombia. Pasturas Tropicales 21 (1):2-17.

Sawkins, M. C., N. Maxted, P. G. Jones, R. Smith, and L. Guarino. 1999. Predicting species distributions using environmental data: case studies using Stylosanthes Sw. Pages 87-99 in S. L. Greene and L. Guarino, editors. Linking genetic resources and geography: emerging strategies for conserving and using crop biodiversity. CSSA Special Publication Number 27. Crop Science Society of America, Madison, Wisconsin, USA.

Schmidt, A., M. Peters, and R. Schultze-Kraft. 2001. Desmodium heterocarpon (L.) DC. subsp. Ovalifolium(Prain) Ohashi. FAO Grassland Index, Rome, Italy.

Schultze-Kraft, R. 2003. Centrosema pubescens se llama ahora Centrosema molle. Pasturas Tropicales 25(2):54-55.

Schultze-Kraft R., W. M. Williams, and J. M. Keoghan. 1993. Searching for new germplasm for the year 2000 and beyond. Pages 70-76 in M. J. Baker, editor. Grasslands for our world. SIR Publishing, Wellington, New Zealand.

Schultze-Kraft, R., R. J. Clements, and G. KellerGrein, editors. 1997. Centrosema: biología, agronomía y utilización. Centro Internacional de Agricultura Tropical (CIAT), Calí, Colombia.

Tarawali, S.A., M. Peters, and R. Schultze-Kraft. 1999. Selecting and testing forage legumes for sustainable agriculture and livestock production in subhumid West Africa. International Livestock Research Institute (ILRI), Ibadan, Nigeria.

van Hintum, T. J. L. 1999. The general 
methodology for creating a core collection. Pages 10-17 in R.C. Johnson and T. Hodgkin, editors. Core collections for today and tomorrow. International Plant Genetic Resources Institute, Rome, Italy.

Vera Aguirre, A. 1997. Transport infrastructure in Latin America. Inter-American Development Bank Report, Volume 35. Inter-American Development Bank, Washington, D.C., USA. Available online at: http://www.iadb.org/INT/Trade/1_english/2_WhatWeDo/ Documents/c OtherPubs/WorkingPapers/f infrastructure. pdf.

Williams, J. T. 1991. The time has come to clarify and implement strategies for plant conservation. Diversity 7:37-39.

Wolf, M. S., and O. R. Southwood. 1980. Plant productivity and persistence in mixed pastures containing Lucerne at a range of densities with subterranean clover or Phalaris. Australian Journal of Experimental A griculture and Animal Husbandry 20:189-196.

Wünscher, T., R. Schultze-Kraft, M. Peters, and L. Rivas. 2004. Early adoption of the tropical forage legume Arachis pintoi in Huetar Norte, Costa Rica. Experimental Agriculture 40:257-268. 